FedUni ResearchOnline

https://researchonline.federation.edu.au

This is the author's accepted version of the following publication:

Zhao, L., \& You, G. (2018) Stability study on the northern batter of MBC Open Pit using Plaxis 3D.Arabian Journal of Geosciences, 11(6), 1-11.

The version displayed here may differ from the final published version.

The final publication is available at:

https://doi.org/10.1007/s12517-018-3454-1

Copyright $@ 2018$, Springer. 


\title{
Stability study on the northern batter of MBC Open Pit using Plaxis3D
}

\author{
Lei Zhao', Greg You ${ }^{1, *}$ \\ ${ }^{1}$ School of Engineering and Information Technology, Federation University Australia, \\ University Drive, Mt Helen, Vic3353, Australia, Email: g.you@ federation.edu.au. \\ * Corresponding author
}

\begin{abstract}
Cracks appeared on the northern batter at Maddingley Brown Coal Open Pit Mine, Victoria, Australia on 8 November 2013 and a heavy rainfall lasting for two days happened a couple of days later. The opening of the cracks varied from trace to $150 \mathrm{~mm}$ wide at about $20 \mathrm{~m}$ back from the coal face and extended for approximately $50 \mathrm{~m}$ on the eastern side and terminated $10 \mathrm{~m}$ away from the access road. An emergency buttress was immediately constructed after the crack and a monitor system of crack movements was established. This study involves in a three dimensional modeling of the effect of the emergency buttress and the rainfall events on the northern batter stability using finite element method (FEM) encoded in Plaxis 3D software program. From the study, it is found that the north batter tended to lead a trend of block sliding after the overburden removal. The simulated location of cracking well agrees with the actual location, and the simulated heave of the coal seam is also in good agreement with the experience in Victoria brown coal open pit mining. The observed vertical crack would be a combined action of the overburden removal and the groundwater flow. The $21 \mathrm{~mm}$ precipitation on 13 Nov 2013 accelerated the development of the cracks and might cause block failure. With the construction of the emergency buttress the batter became stable that is in good agreement with the monitored data. The calculated safety factor are 1.38, 1.17, 1.13, 1.14 and 1.43 for initial north batter model, model after overburden removal, model with a $21 \mathrm{~mm}$ precipitation in a day, model with a $7.6 \mathrm{~mm}$ precipitation in a day, and model with buttress, respectively.
\end{abstract}

Key Words: batter stability, brown coal, ground crack, open pit mining, rainfall, buttress

\section{INTRODUCTION}

Up to $65 \%$ of coal production adopts surface or opencast mining in Australia (Scoot et al. 2010). Especially in Victoria Australia open pit mining is almost the only mining method to extract the huge quantity of reserved brown coal. Although open pit mining is generally away from the risks of mine roof collapses, gas explosion, ventilation issues, slope failure is a big geotechnical problem. Slope 
Table 1 Failures reported in Victorian brown coal open pit

\begin{tabular}{|c|c|c|}
\hline Location & Failure Type & Year \\
\hline $\begin{array}{l}\text { Yallourn North Open } \\
\text { Cut Mine }\end{array}$ & $\begin{array}{l}\text { two slips along clay seams below the coal } \\
\text { occurred }\end{array}$ & $\begin{array}{c}1950 \text { and } 1957 \\
\text { (Learmonth 1985) }\end{array}$ \\
\hline $\begin{array}{c}\text { Maddingley Brown } \\
\text { Coal Open Pit }\end{array}$ & tension cracks appeared in the southern wall & 1994 \\
\hline $\begin{array}{c}\text { Yallourn East Field } \\
\text { Mine }\end{array}$ & Batter failure & $\begin{array}{l}\text { 14th November } 2007 \\
\text { (Mining Warden 2008) }\end{array}$ \\
\hline Yallourn Mine & $\begin{array}{c}\text { an embankment failed during an extreme } \\
\text { rainfall }\end{array}$ & 2012 (Hepburn 2014) \\
\hline $\begin{array}{l}\text { Morwell Open Cut } \\
\text { Mine }\end{array}$ & $\begin{array}{l}\text { rotational circular slip in overburden while } \\
\text { block and wedge failures formed in brown coal }\end{array}$ & (Learmonth 1985) \\
\hline
\end{tabular}

Victorian brown coal is high in organic content (>90\%), but low in hydraulic conductivity according to Durie (1991), Liu et al. (2014), Xue and Tolooiyan (2012). Unique consolidation behaviors such as 
large deformation, immediate settlement after loading and low permeability were shown in one dimensional consolidation tests conducted by Liu et al. (2016). The strength of Victorian brown coal is between normal engineering soils and rocks. And the average undrained shear strength of brown coal is between 550 and 1,100 kPa that reported by Rosengren (1961) and Trollope et al. (1965). From Tolooiyan et al. (2014) the average tensile strength of the brown coal sample is $101.4 \mathrm{kPa}$ from direct tensile tests and is $112 \mathrm{kPa}$ based on the Brazilian test.

Maddingley Brown Coal (MBC) open pit is a small-scale mine, located 60km northwest of Melbourne, Victoria, Australia. The coal seam is typically $35 \mathrm{~km}$ in length, $10 \mathrm{~km}$ to $15 \mathrm{~km}$ in width and from $35 \mathrm{~m}$ to $60 \mathrm{~m}$ in thickness. The coal is rarely fractured and is predominantly a dark brown earthy variety of lignite with little impurity known as a small percentage of the matrix maybe silty or sandy. Three main hydrostratigraphic units underlying mine site. Fyansford Formation, as the most upper aquifer with a thickness of 5-20m, consists mainly of silts, sands, clays, and overlying Quaternary sediments; the Maddingley Coal Seam is regarded as an aquitard separating the upper unconfined Fyansford Formation from the lower confined Werribee Formation, due to its high clay content and low hydraulic conductivity $\left(10^{-8} \mathrm{~m} / \mathrm{s}\right)$; the lower Werribee formation consists of mainly silty soils and sands.

\section{FIELD INVESTIGATION}

The northern batter of MBC had been stable for many decades without any mining activities until in the early 2013 when the overburden stripping activities commenced. The overburden was stripped ahead of the northwards coal mining. The north coal batter was approximately $25 \mathrm{~m}$ high in a single bench, at a slope angle $>80$ degrees. There was an old $5 \mathrm{~m}$ high toe buttress (brown coal) providing support to the bench at the western end of the coal bench (Fig.1). 


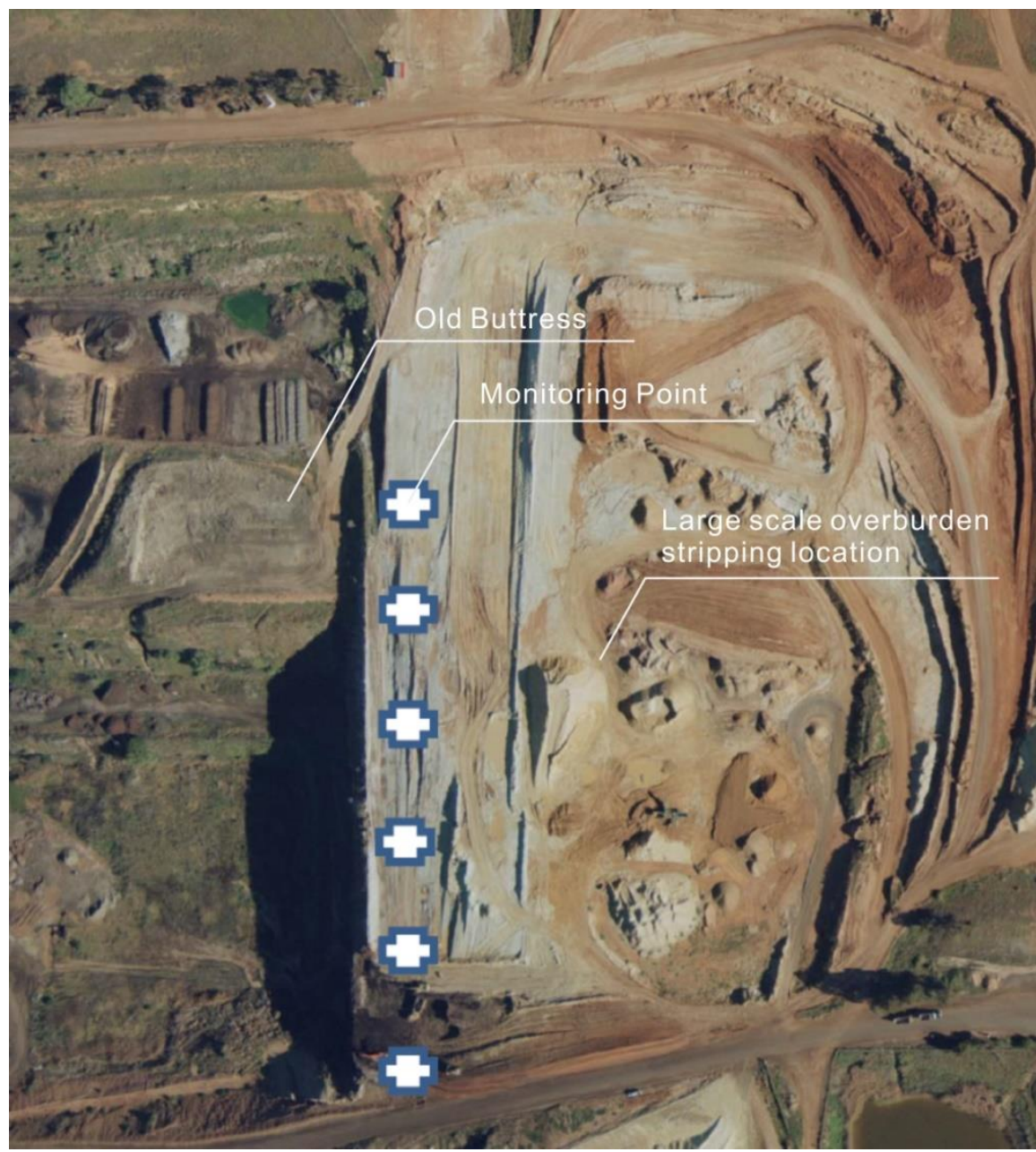

Fig.1 North batter coal face with the monitoring system established immediately after the observation of crack

On 8 November 2013 east-west striking cracks were observed on the top of coal seam approximately $20 \mathrm{~m}$ from the crest of the coal face. Five days later a heavy rainfall event lasting for two days happened on MBC. The precipitation was about average $21 \mathrm{~mm}$ on $13 \mathrm{Nov}$ and $7.6 \mathrm{~mm}$ on 14 Nov based on the record data of the nearest bureau stations of Merrimu Reservoir, Melton and Melton Reservoir (Australian Government Bureau of Meteorology 2013). The cracks were inspected after the rainfall event. The aperture varied from trace to $150 \mathrm{~mm}$ wide (Fig.2) extended $50 \mathrm{~m}$ and terminated $10 \mathrm{~m}$ away from the access road on the eastern side. The aperture was wider in the east than in the west. The less horizontal movement in the west would benefit from the toe buttress (Fig.1). 


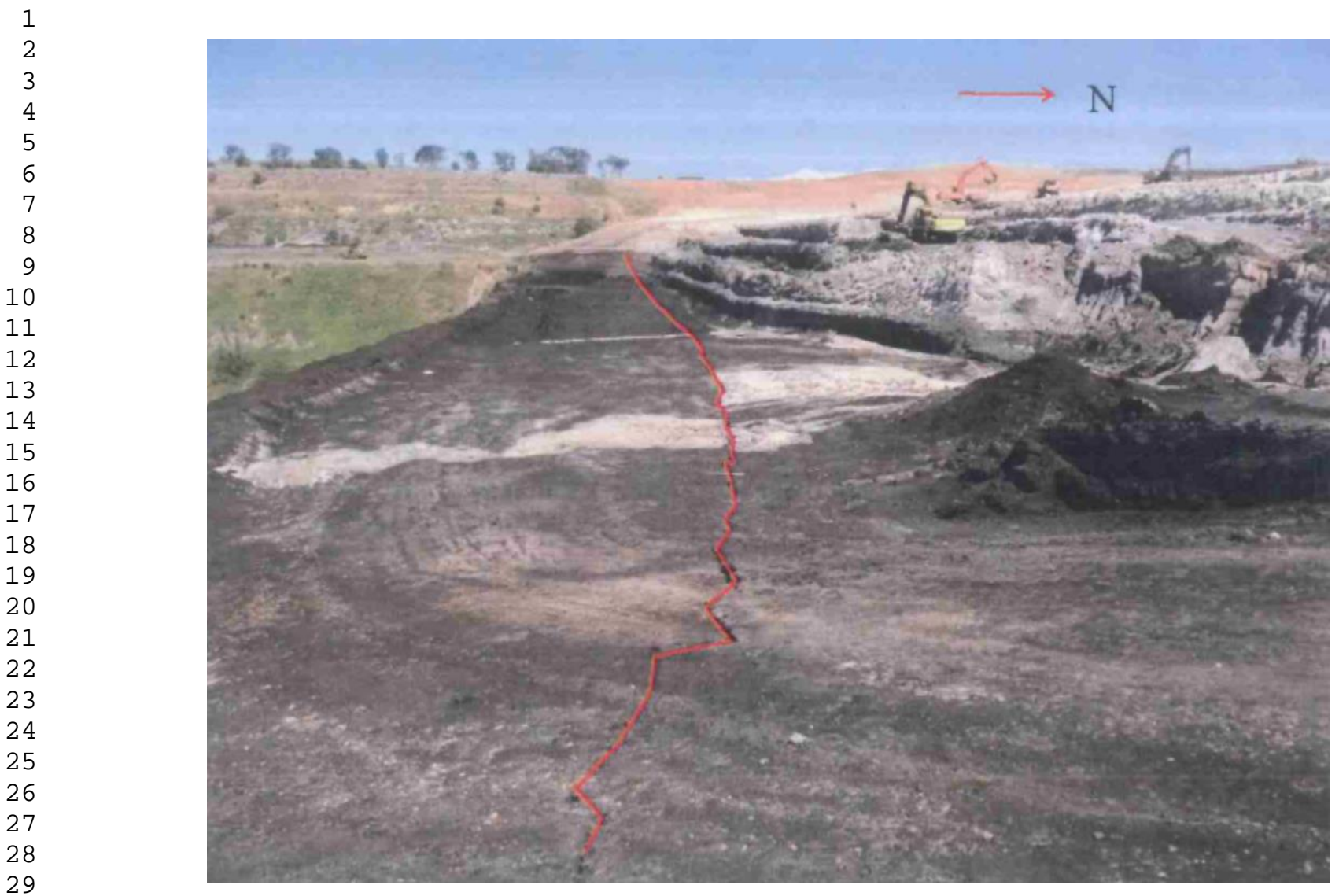

Fig.2 Crack on the coal seam (looking towards west)

To improve the stability of the batter, construction of an emergency buttress commenced immediately after the observation of cracks and was completed on 13 February 2014. The two levels emergency buttress comprised an approximately $12 \mathrm{~m}$ high earth fill, extending out approximately $40 \mathrm{~m}$ from the face. The dimensions of the buttress are shown in Fig.3.

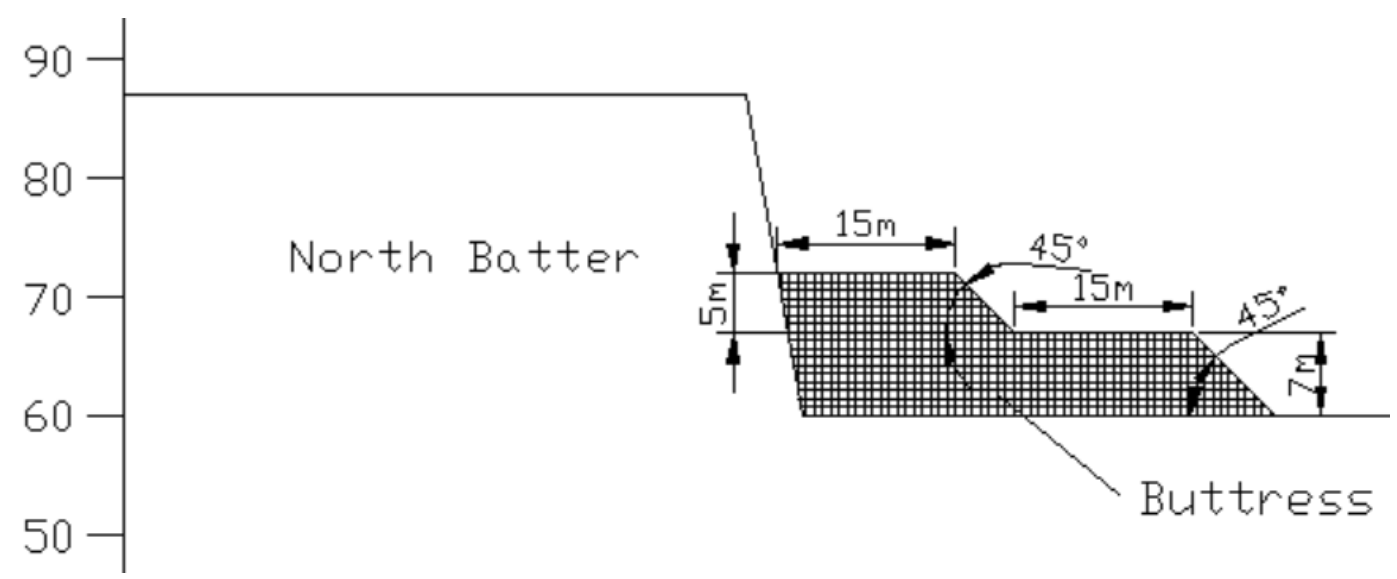

Fig.3 Illustration of the emergency buttress 


\section{IN SITU MONITORING}

A number of survey markers were installed on north batter on 19 November 2013 (Fig.1) to monitor the displacements of the batter. This monitoring result was reported weekly till the early 2014 when the survey markers were destroyed by mining activity. The movements of the crack were shown from Fig.4 to Fig.6. The southwards movement and upwards heave were dominant deformations (see Fig.4 and Fig.6, respectively).

\section{Date}

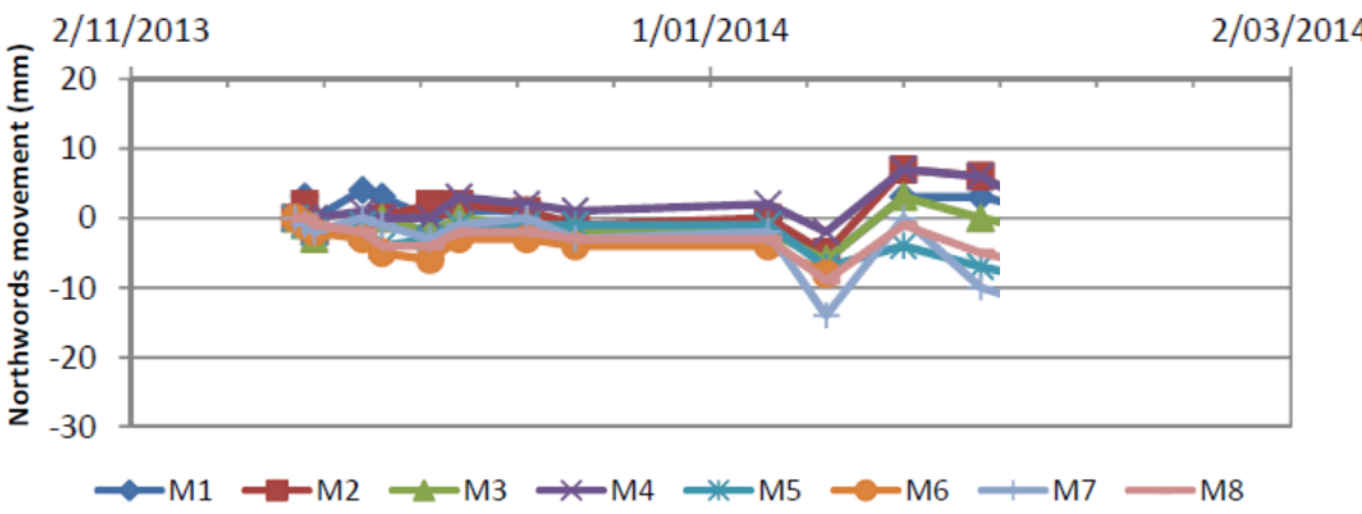

Fig.4 Northwards movements of cracks

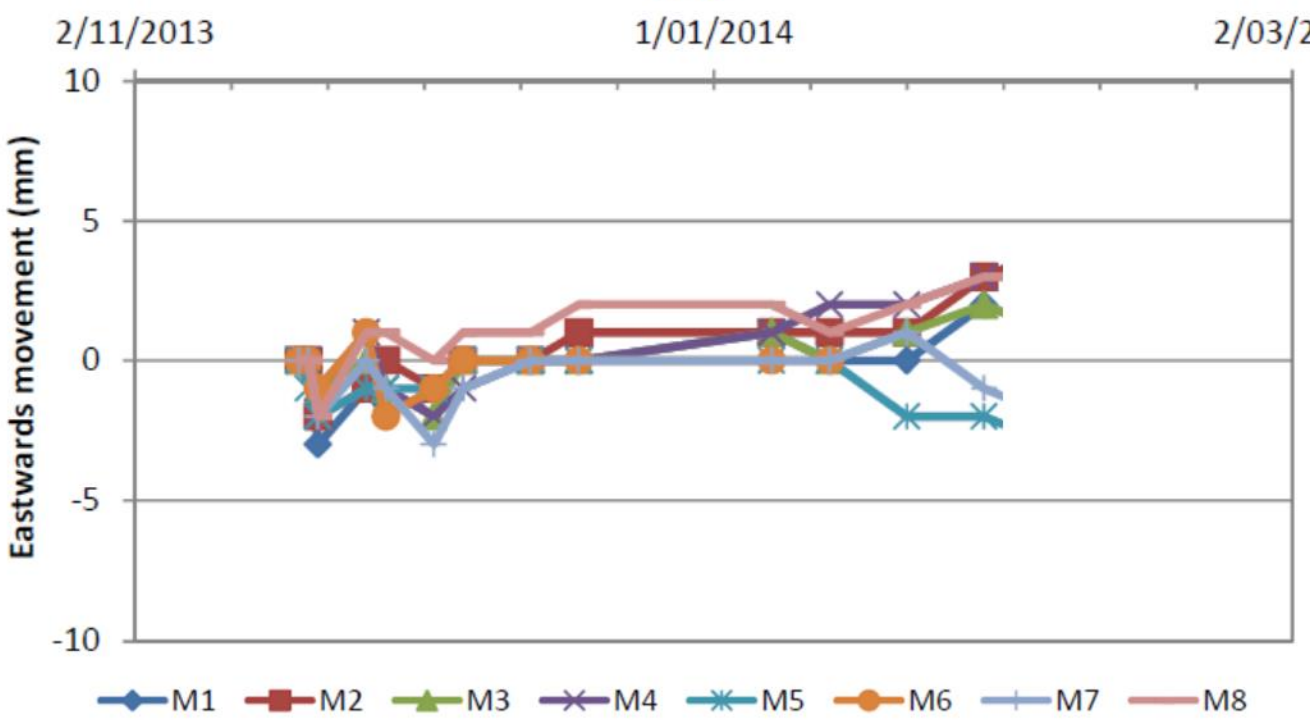

Fig.5 Eastwards movements of cracks 


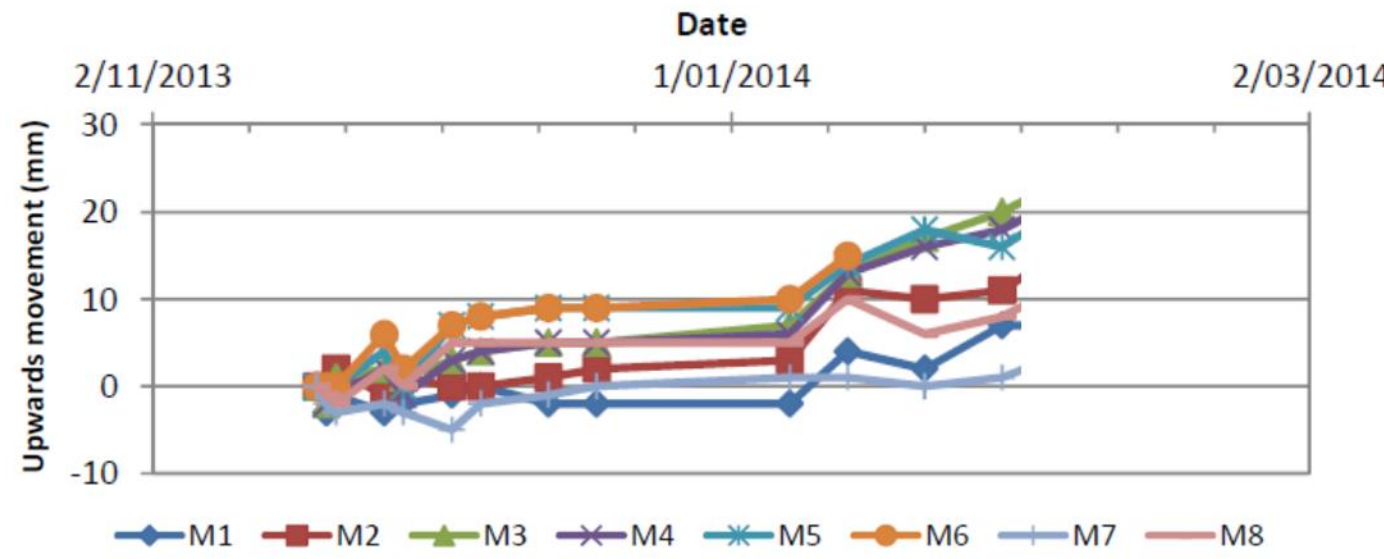

Fig.6 Upwards movements of cracks

\section{D GEOLOGICAL MODEL AND SIMULATION DESIGN}

A three-dimensional geological model with dimensions of 200m long, 100m wide and 109m high was generated from an aerial survey map of June 2012 with $1 \mathrm{~m}$ interval of contour. Strata represented in the model are Fyansford Formation (overburden, 87m-109m), Intact Maddingley Brown Coal (5087m), Werribee Formation (0-50m), Engineering Fill Layer (55-60m), Broken Coal Layer (50-55m) and Emergency Buttress (60-72m) (Fig.7). To obtain an accurate result of simulation, the whole model was meshed as very fine element distribution and the batter part was refined meshed. Parameters adopted for different layers were from technical reports of MBC, involved in direct shear tests, triaxial tests and permeability tests. The groundwater table was set at RL $91 \mathrm{~m}$ in the north and at RL 60m at the pit bottom; the water flow direction was from north to south (from the north batter to the pit bottom).

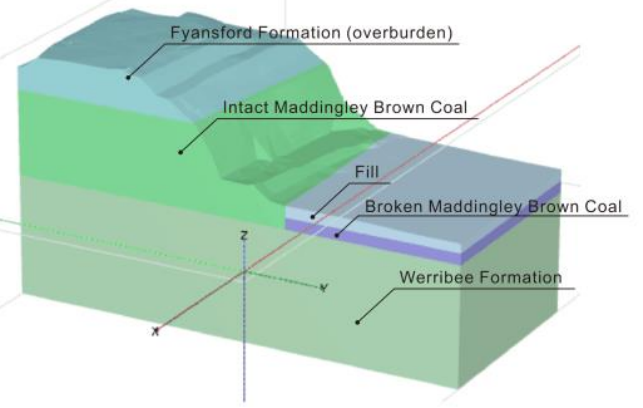

(a) Geological model (without buttress)

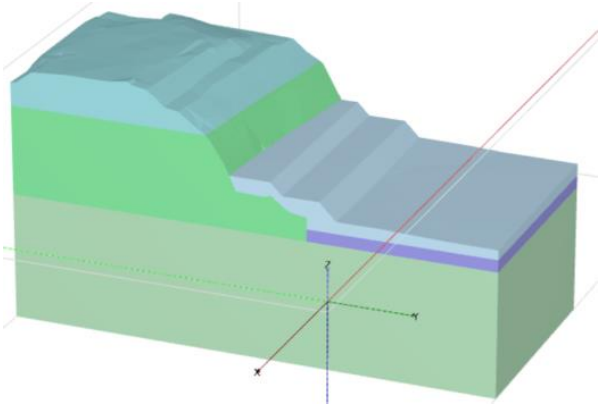

(b) Geological model (with buttress) 


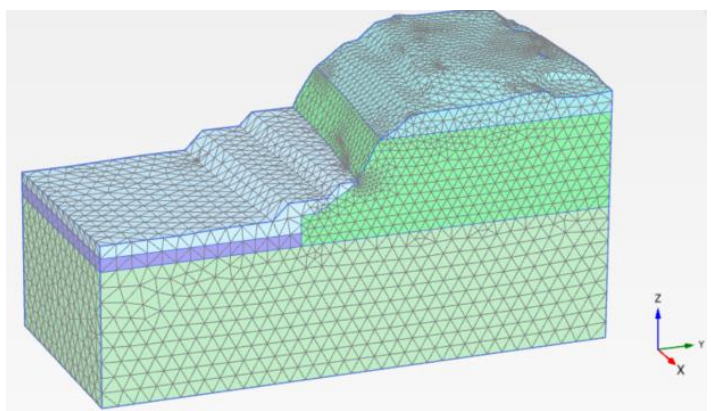

(c) Plaxis 3D FEM mesh

Fig.7 3D Model: (a) Geological model (without buttress), (b) Plaxis 3D FEM (with buttress), (c) mesh (in very fine mesh)

Table 2 Soil properties adopted

\begin{tabular}{|c|c|c|c|c|c|c|}
\hline Layer & Unit & $\begin{array}{l}\text { Fyansford } \\
\text { Formation }\end{array}$ & $\begin{array}{l}\text { Intact } \\
\text { MBC }\end{array}$ & $\begin{array}{l}\text { Werribee } \\
\text { Fornation }\end{array}$ & $\begin{array}{c}\text { Broken } \\
\text { MBC }\end{array}$ & $\begin{array}{c}\text { Fill \& } \\
\text { Buttress }\end{array}$ \\
\hline Drainage Type & - & Drained & Drained & Undrained A & Drained & Drained \\
\hline $\begin{array}{l}\text { Unsaturated } \\
\text { Unit weight }\end{array}$ & $\mathrm{kN} / \mathrm{m}^{3}$ & 16 & 5 & 17 & 5 & 15 \\
\hline $\begin{array}{c}\text { Saturated } \\
\text { Unit weight }\end{array}$ & $\mathrm{kN} / \mathrm{m}^{3}$ & 19 & 11.5 & 20 & 11.5 & 18 \\
\hline Poisson's ratio & - & 0.3 & 0.27 & 0.3 & 0.27 & 0.3 \\
\hline Cohesion & $\mathrm{kN} / \mathrm{m}^{2}$ & 9 & 150 & 5 & 20 & 5 \\
\hline Friction angle & o & 27 & 30 & 30 & 30 & 30 \\
\hline Young's modulus & $\mathrm{kN} / \mathrm{m}^{2}$ & 130 & 37 & 95 & 37 & 15 \\
\hline Dilatancy angle & o & 0 & 0 & 0 & 0 & 0 \\
\hline $\begin{array}{c}\text { Horizontal } \\
\text { permeability } \mathrm{k}_{\mathrm{x}}\end{array}$ & $\mathrm{m} / \mathrm{d}$ & 0.0086 & 0.0086 & 0.00086 & 0.1 & 0.1 \\
\hline $\begin{array}{c}\text { Horizontal } \\
\text { permeability } \mathrm{k}_{\mathrm{y}}\end{array}$ & $\mathrm{m} / \mathrm{d}$ & 0.0086 & 0.0086 & 0.00086 & 0.1 & 0.1 \\
\hline $\begin{array}{c}\text { Vertical } \\
\text { permeability } k_{z}\end{array}$ & $\mathrm{~m} / \mathrm{d}$ & 0.00086 & 0.00086 & 0.00086 & 0.1 & 0.1 \\
\hline
\end{tabular}

The main purpose of this numerical simulation is to study the stability of northern batter of MBC under the conditions of overburden removal, rainfall and buttress construction. Five stages including eleven calculation phases are included in the numerical simulation design (Fig.8). 


\section{Phases}

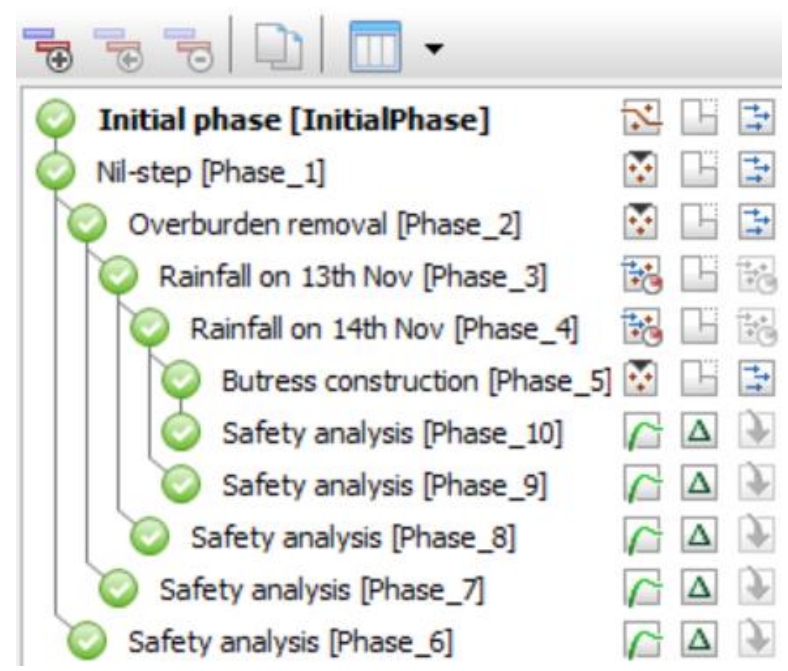

Fig.8 Numerical simulation design

\section{Stage 1}

The initial phase defined by gravity loading is to simulate the initial state of the northern batter that had been stable for decades without any mining activity, and followed by a nil-step phase and a safety analysis phase. Nil-step is a normal plastic calculation designed after the initial phase, with the purpose of rebalancing the existing out-of-balance stress generated by the gravity loading of initial phase.

\section{Stage 2}

This stage is designed to simulate the effect of overburden removal on batter stability. It includes a plastic calculation phase and a safety analysis phase.

\section{Stage 3}

This stage is to illustrate how the $21 \mathrm{~mm}$ rainfall event on 13 Nov 2013 affects the crack development and the batter stability. The calculation type of rainfall phase is fully coupled flow-deformation; time interval is set as one day and precipitation intensity is $21 \mathrm{~mm} /$ day. A phase of safety analysis follows this rainfall phase.

Stage 4

Similar to Stage 3, this stage is to simulate a 7.6mm precipitation on 14 Nov 2013 on northern batter. One day of time interval and $21 \mathrm{~mm} /$ day of precipitation intensity are set. It also includes a safety analysis phase. 
This stage is to simulate the effect of the emergency buttress construction. A safety analysis phase is included in this stage.

\section{RESULTS AND ANALYSIS}

The coal seam model after overburden removal (Stage 2) was likely to slide as a block while the critical path of potential batter instability for the initial model (Stage 1) tended to be circular. The calculated safety factors were 1.38 and 1.17 for Stage 1 and Stage 2 respectively. After the overburden removal, the incremental Cartesian normal strain of stage 2 in the yy direction, e.g. $\Delta \varepsilon_{y y}$, was between 0.04 and 0.06 on top and bottom of the coal seam in the Stage 2 model (Fig.9). It might be inferred that the top coal seam experienced tensile failure at the location of about $20 \mathrm{~m}$ from the crest in Stage 2 as the range of tensile strain limit for Victorian brown coal is between 0.005 and 0.01 reported by Tolooiyan et al. (2014). The calculated safety factors of Stage 1 and Stage 2 are in line with the mining experience of Victorian brown coal open pits; the location of the possible cracks simulated on Stage 2 agrees well with the actual location of observed cracks. In addition, the coal seam heaved $0.22 \mathrm{~m}$ after overburden (average $15 \mathrm{~m}$ thick) removal as simulated in Stage 2. This is in good agreement with the experience in Victorian open pit brown coal mines. The report of "Geotechnical assessment northern coal batter" prepared for MBC by Golder Associates Pty Ltd reported that a removal of $10 \mathrm{~m}$ thick overburden could generate a heave of about $0.15 \mathrm{~m}$. Moreover the simulated $0.22 \mathrm{~m}$ heave matches the monitored data shown in Figure 7, from which the maximum upwards displacement reached about $0.22 \mathrm{~m}$ as recorded in February 2014 


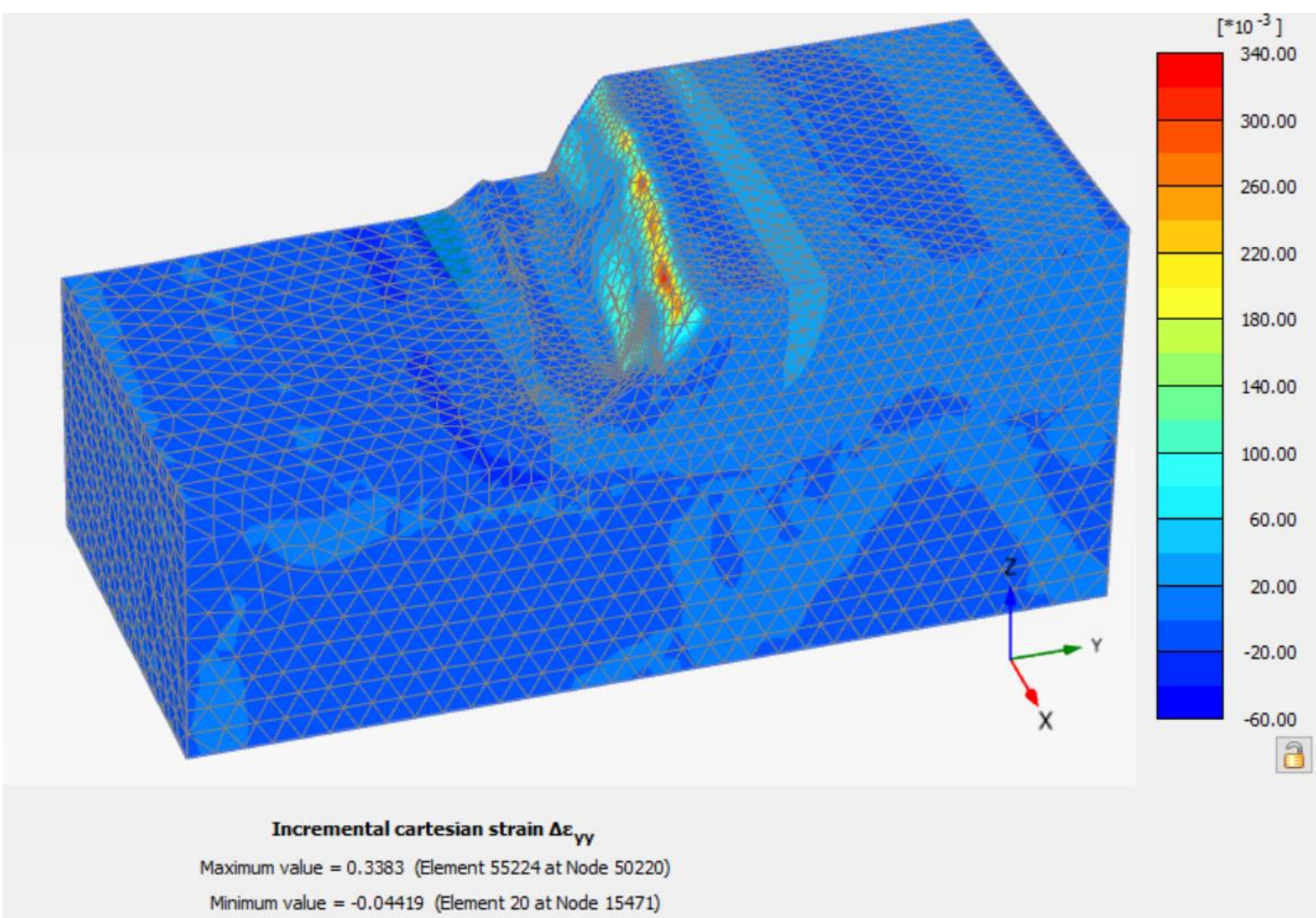

Fig.9 Incremental Cartesian tensile strain of Stage 2

The safety factor dropped from 1.17 to 1.13 after a 26mm rainfall event on 13 November 2013 (Stage 3 model) while it increased to 1.14 after the $7.6 \mathrm{~mm}$ rainfall the following day (Stage 4 model). Along the sliding path, the incremental deviatoric strain generated at Stage 3 (0.3 to 0.5) (Fig.10 (a)) was larger than that at Stage 4 (0.1 to 0.2) (Fig.10 (b)). From Fig.11 and Fig.12, both incremental displacement (1.0 to 1.2) and incremental Cartesian strain (about 0.4) generated along the sliding path at Stage 3 are larger than those at Stage 4 (0.4 to 0.6 and about 0.2 , respectively). From these simulated results rainfall accelerates the development of the cracks; especially the high intensity rainfall is more likely to cause a block failure. The decrease of suction and increase of water pressure in the soil, caused by rain water infiltration, are considered as the reason to decrease the shear strength of the sliding path and could eventually cause a batter failure. 


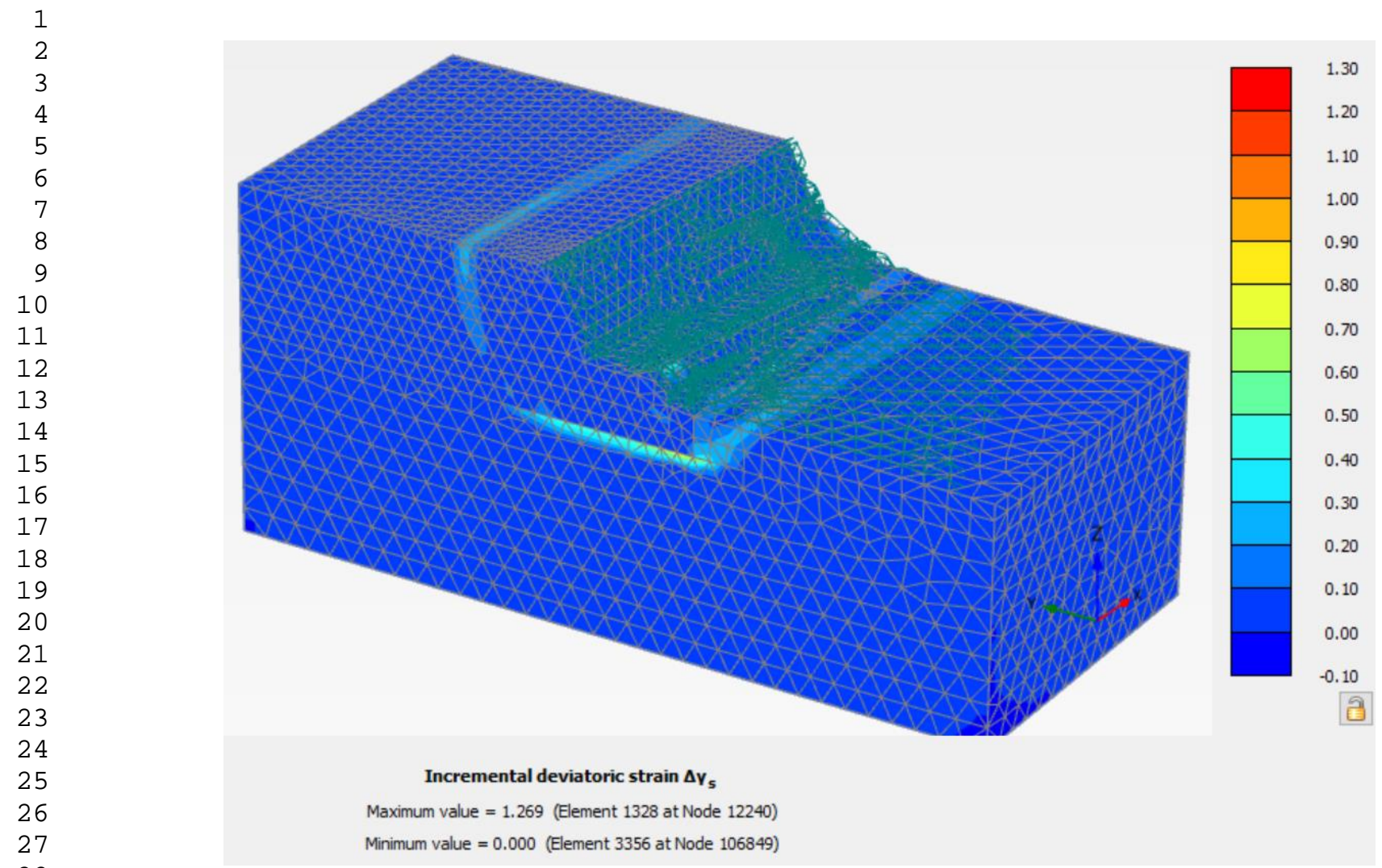

(a) Stage 3, after $21 \mathrm{~mm}$ rainfall on 13 November 2013

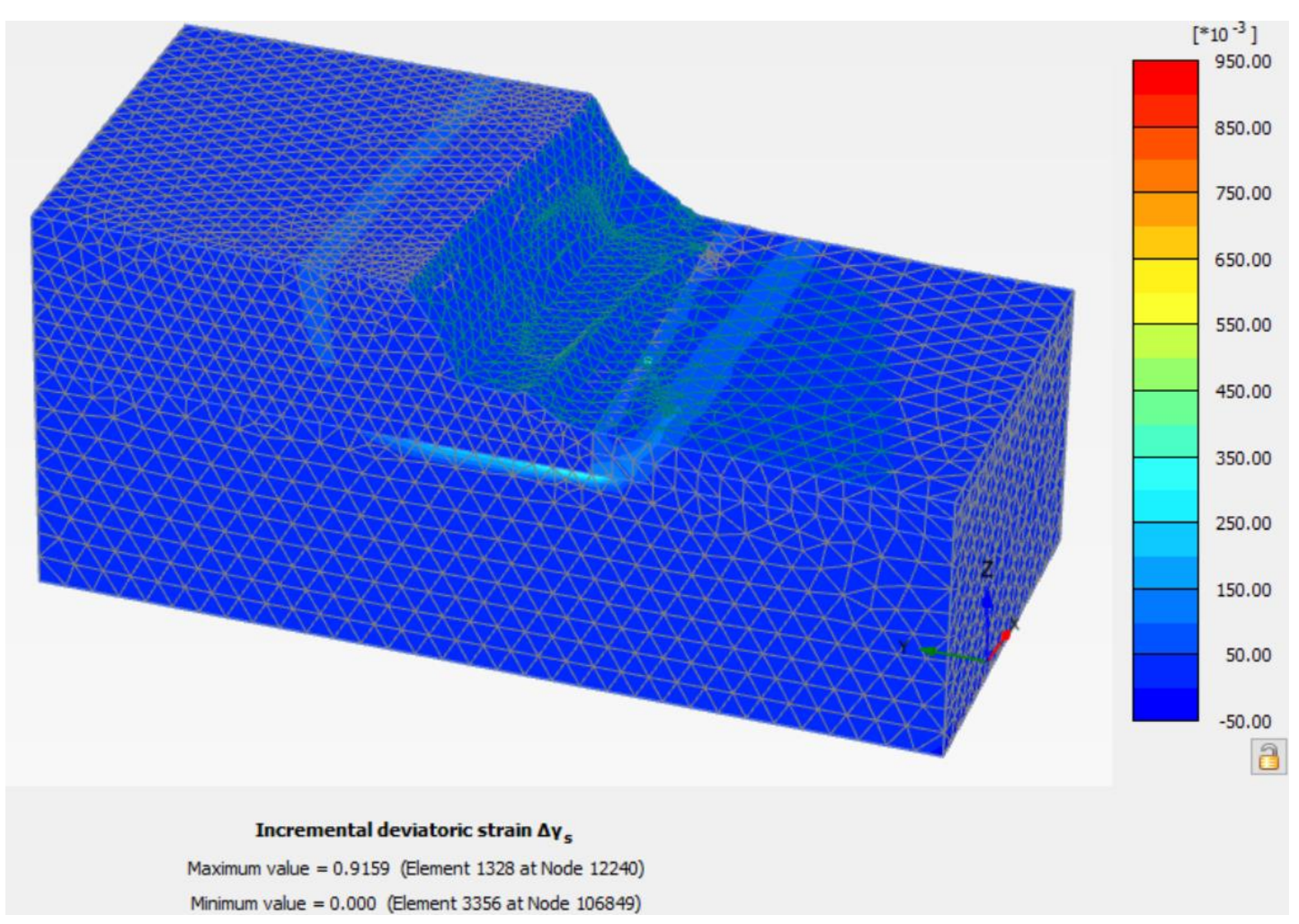


1 (b) Stage 4, after 7.6mm rainfall on 14 November 2013

Fig.10 Incremental deviatoric strains resulted from safety analysis:

(a)Stage 3; (b) Stage 4

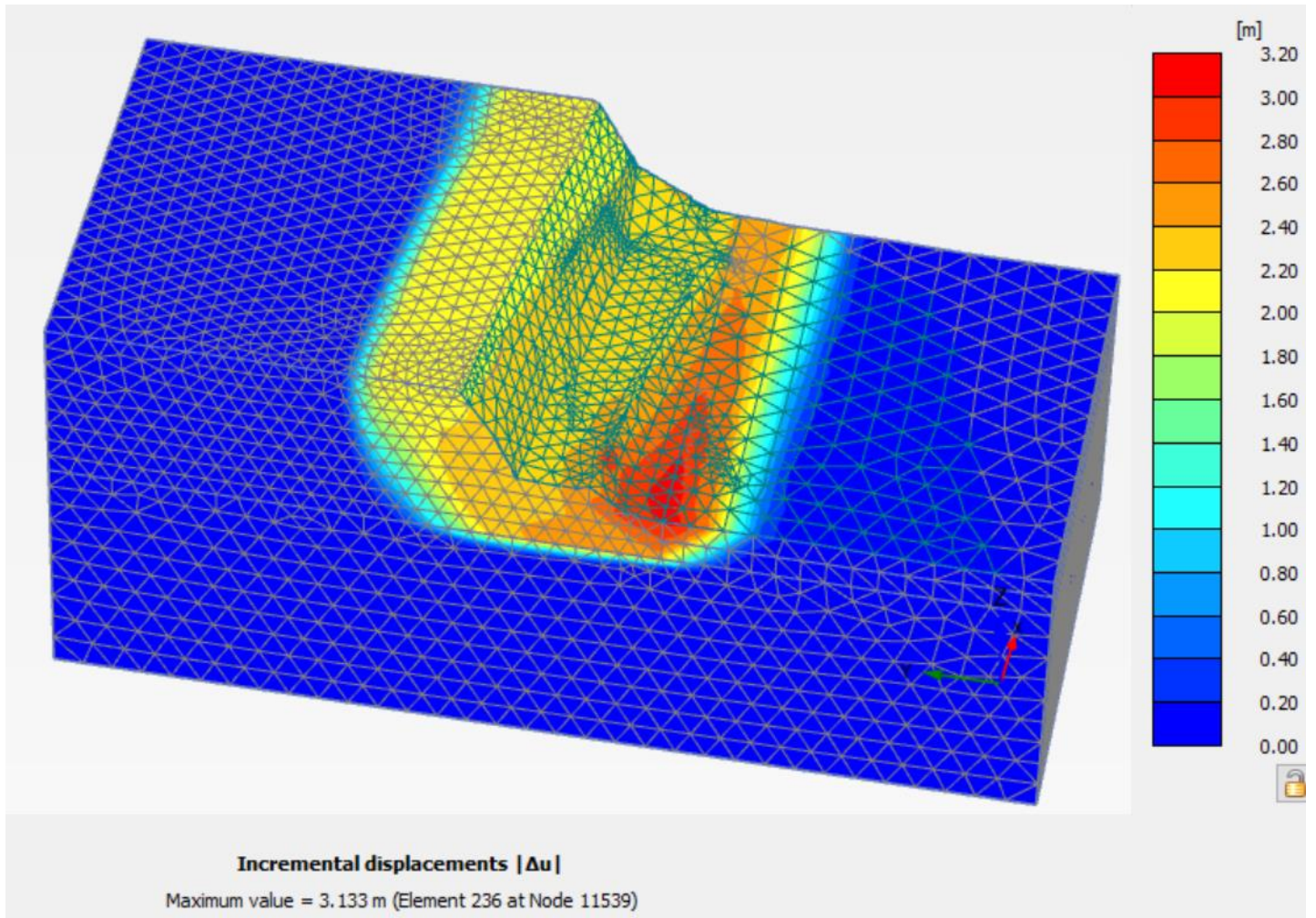

(1) Stage 3, after $21 \mathrm{mmmm}$ rainfall on 13 November 2013 


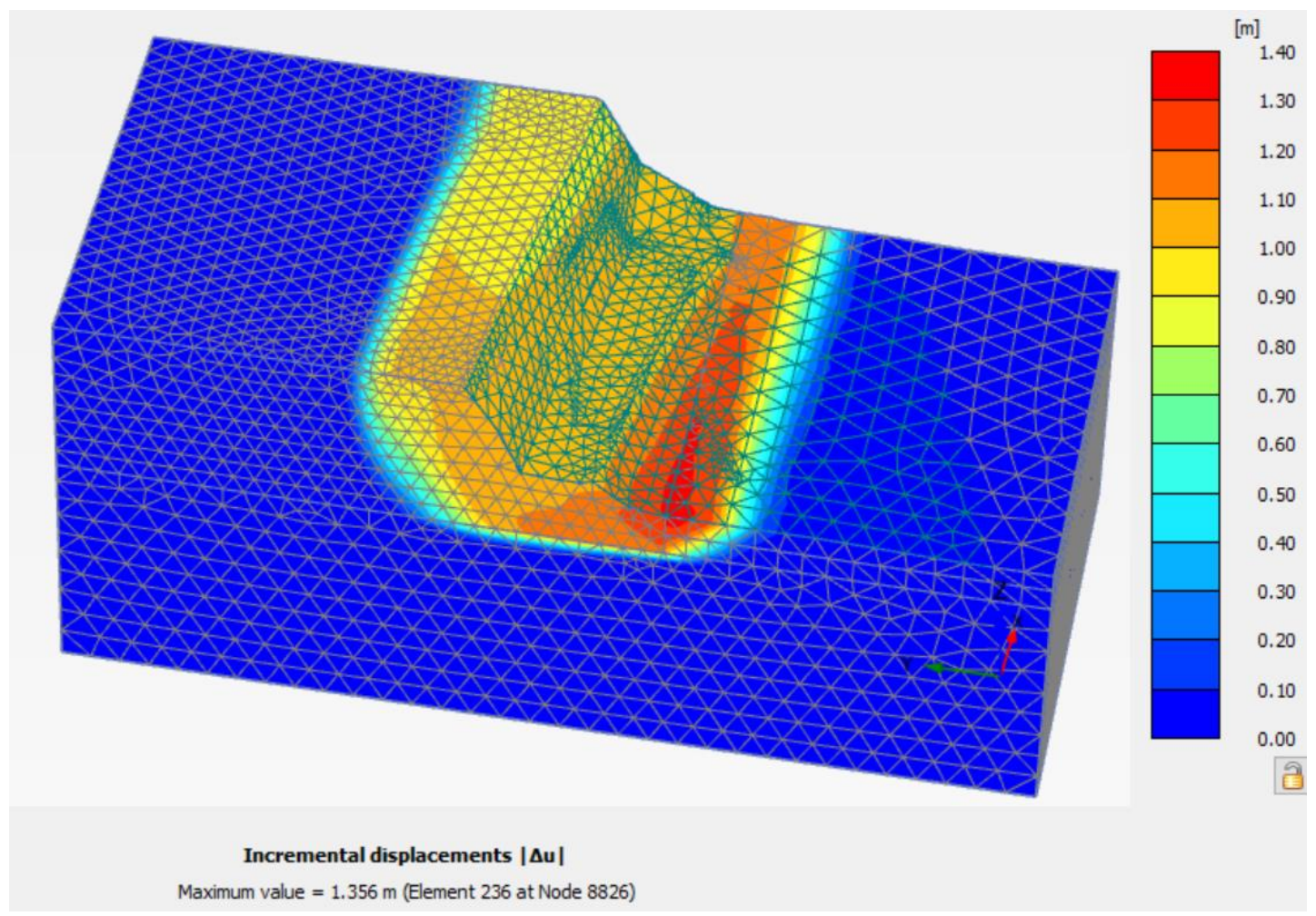

(b) Stage 4, after 7.6mm rainfall on 14 November 2013

Fig.11 Incremental displacement resulted from safety analysis:

(a) Stage 3; (b) Stage 4 
1

2
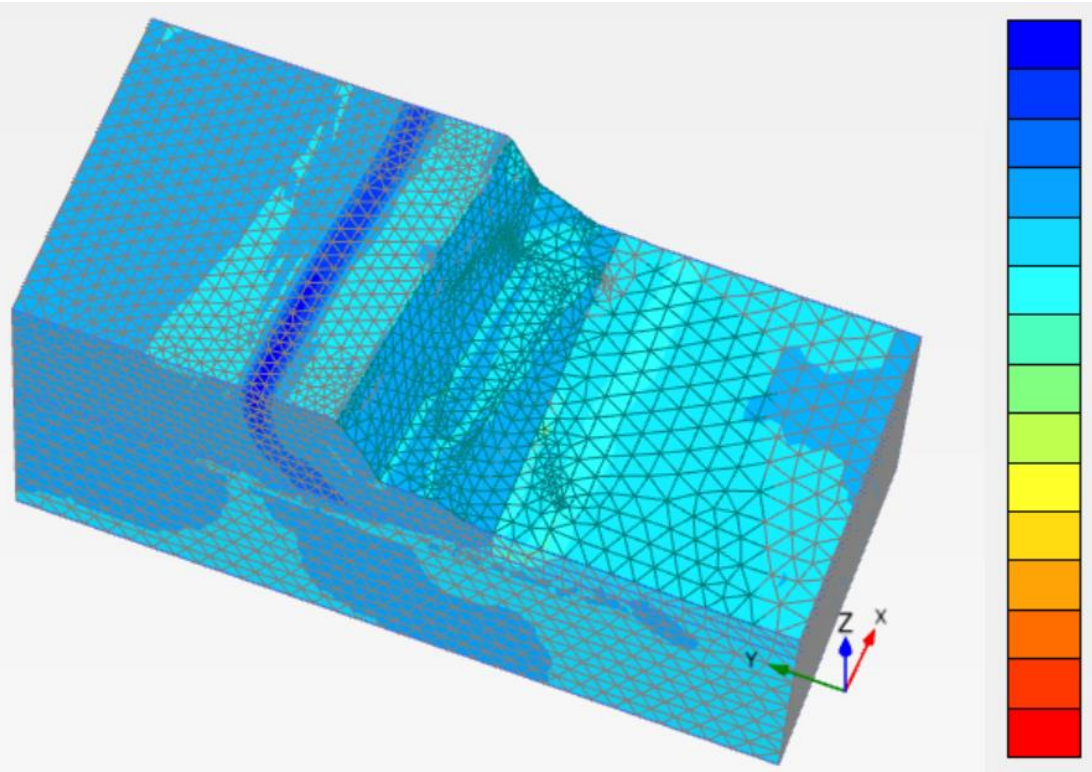

\section{Incremental cartesian strain $\Delta \varepsilon_{\mathrm{yy}}$}

Maximum value $=0.3656$ (Element 58602 at Node 66238)

Minimum value $=-1.007$ (Element 1328 at Node 12240)

(1) Stage 3, after $21 \mathrm{~mm}$ rainfall on 13 November 2013

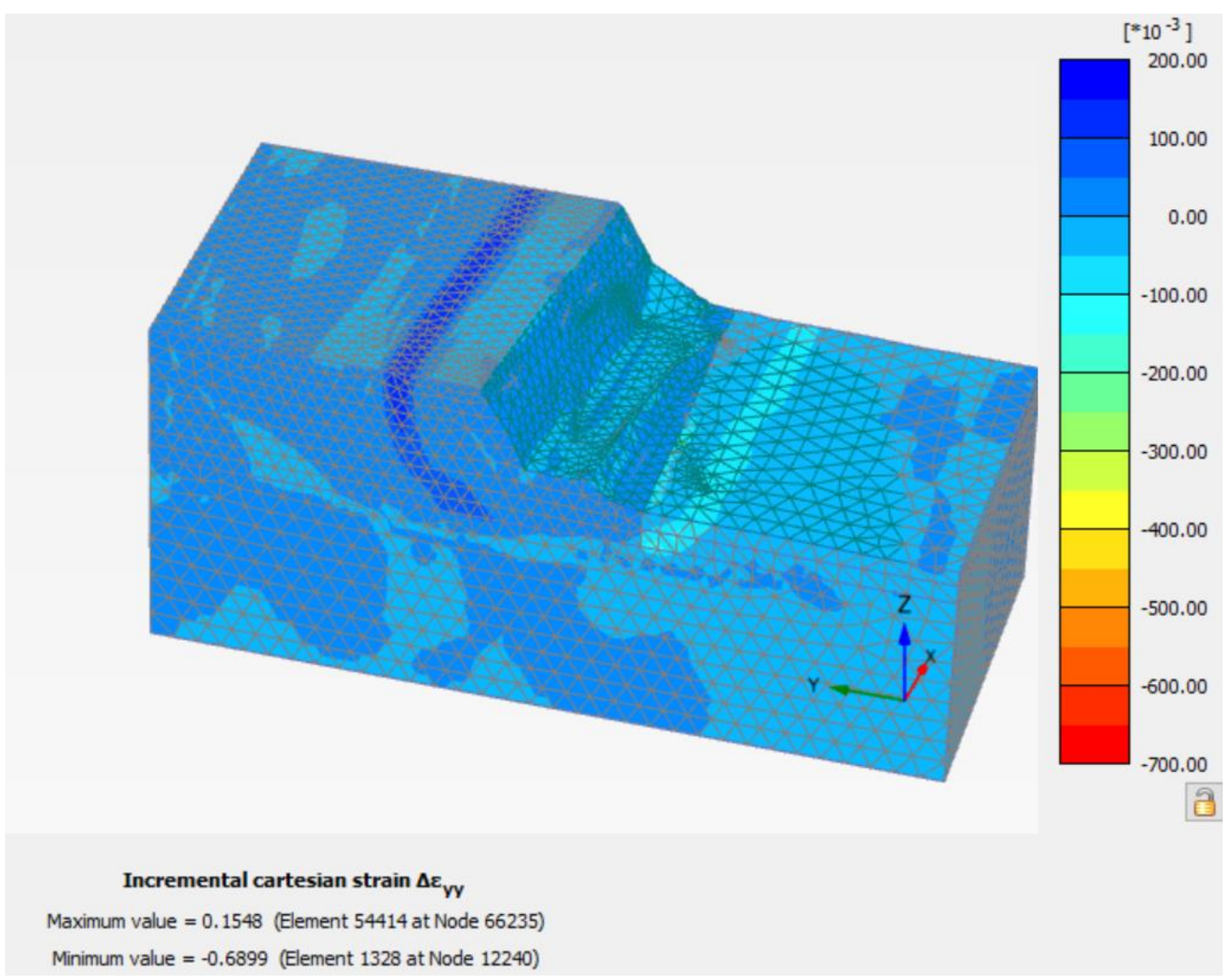


Fig.12 Incremental Cartesian strain resulted from safety analysis:

(a) Stage 3; (b) Stage 4

Stage 5 model simulates the stability state of the northern batter after the completion of buttress construction. From Fig.13 and Fig.14, no apparent incremental displacement or incremental deviatoric strain is seen on the batter. The safety factor of the batter is increased to1.43, which is much higher than 1.13 at Stage 3 and higher that 1.38 at the initial stage. The batter is believed in a stable state at Stage 5 with the support of buttress. Also the monitored data in terms of northwards displacement (Fig.4) and eastwards movements (Fig.5) evidenced that the movement of the cracks had been controlled with the construction of buttress; the minor fluctuation of movements were caused by rainfall in February 2014. A fact that cannot be neglected is the possible existing joints in the coal seam. Steeply dipping tight joints filled with white clay were observed, and a prominent joint was observed at the south eastern coal face according to the report of "Mine risk issues assessment" prepared for MBC by Golder Associates Pty Ltd. However, this study did not consider the effect of the possible pre-existing joints and clay (not observed on north batter) within coal seam of the north batter.

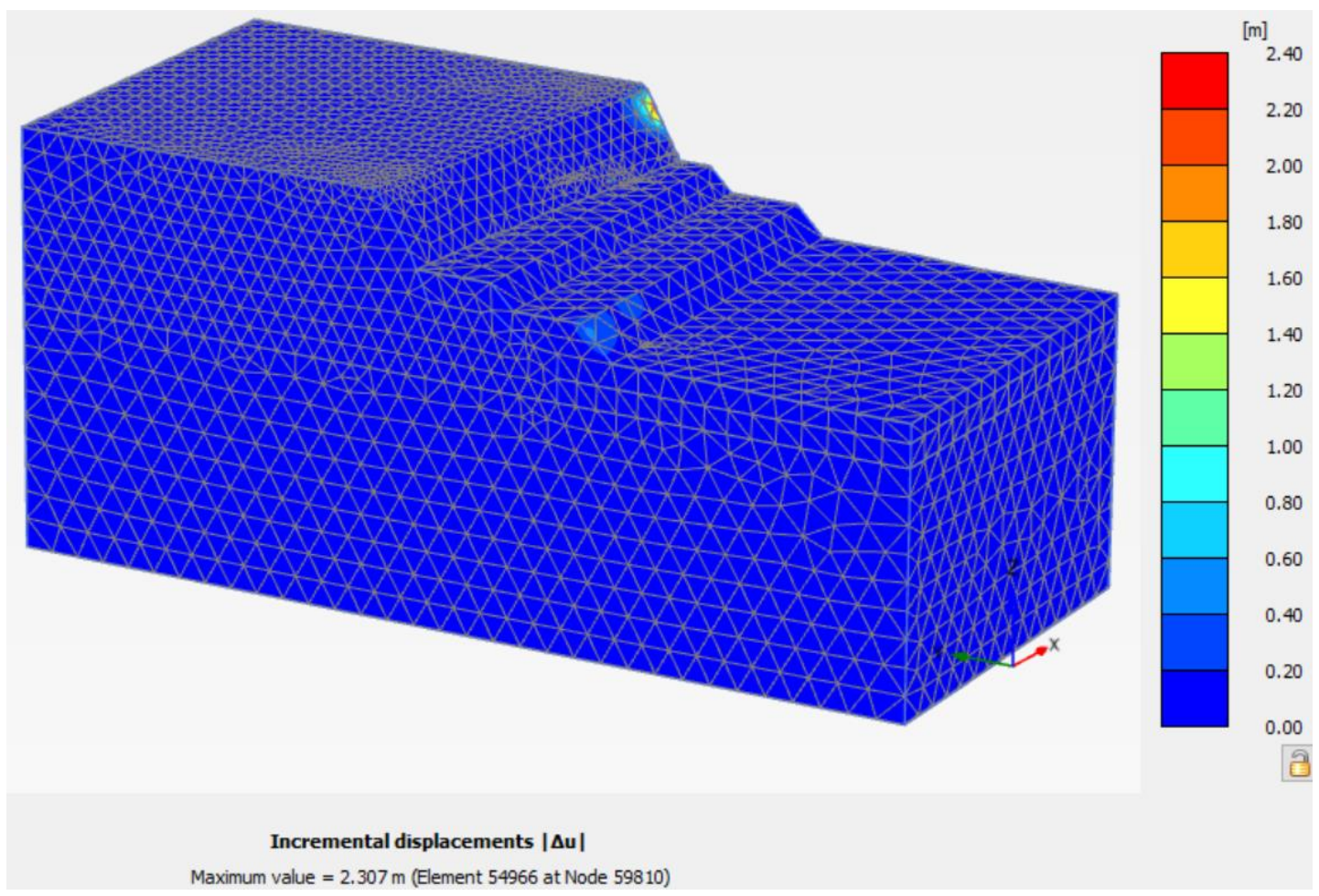

Fig.13 Incremental displacement resulted from safety analysis: Stage 5 of buttress construction 


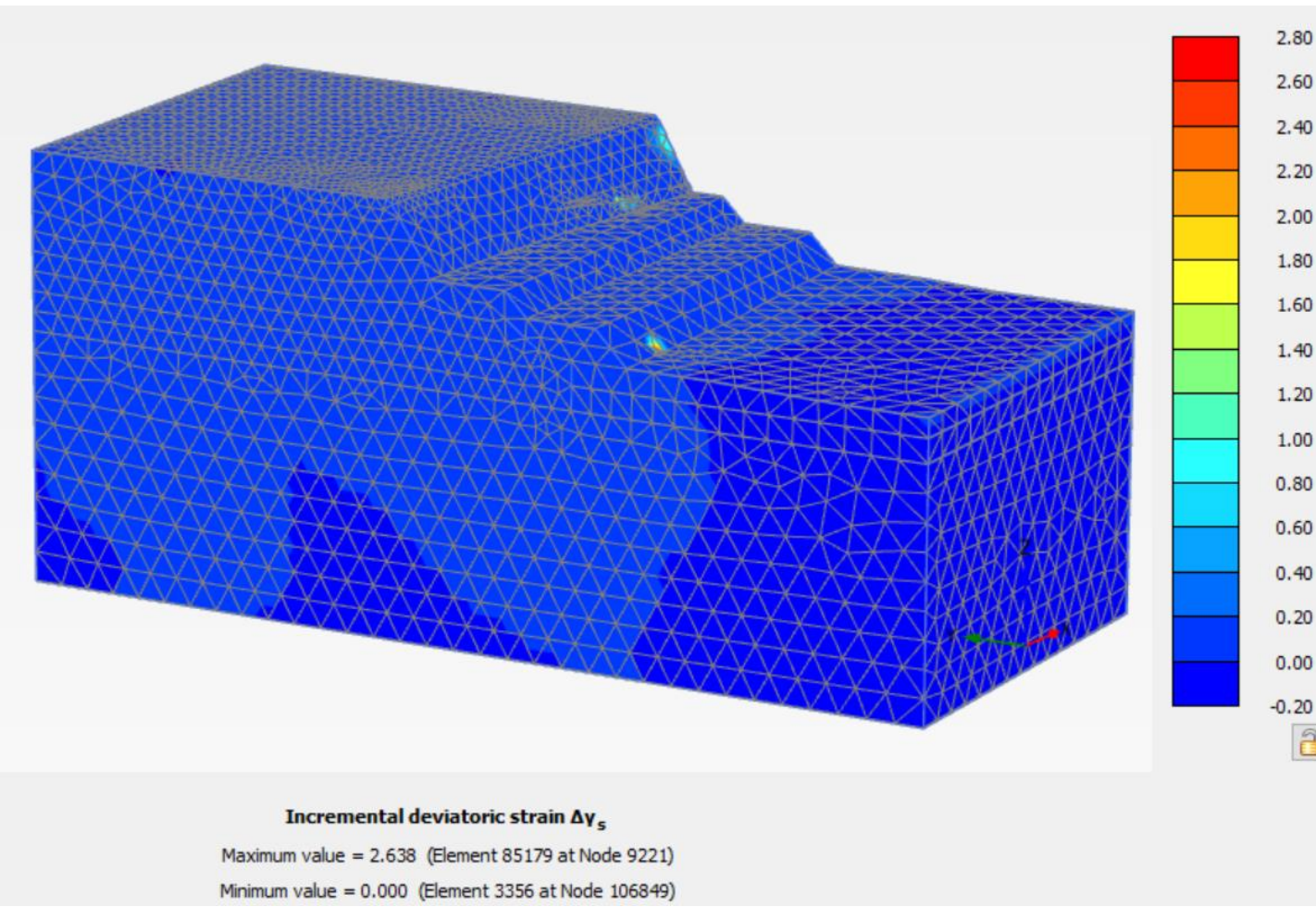

Fig.14 Incremental deviatoric strain resulted from safety analysis: Stage 5 of buttress construction

\section{CONCLUSION}

A 3D numerical model was established using Plaxis 3D FEM program to investigate the north batter stability at Maddingley Brown Coal Open Pit Mine, Victoria, Australia. The following conclusions are drawn from this study.

1. According to the mining experience of Victorian brown coal open pit based on the reports provided by Golder Associated Pty Ltd, the original stable northern batter was estimated with a safety factor between 1.22 and 1.60; however it would decrease to 1.03 to 1.30 for failure as the result of overburden removal. The calculated safety factors 1.38 for original north batter (Stage 1) and 1.17 after the removal of overburden (Stage 2) agree very well with the experience.

2. After a high intensity rainfall on 13 November 2013 the safety factor of north batter dropped from 1.17 to 1.13 , but after a lower intensity rainfall the second day the safety factor increased to 1.14. The incremental displacement and incremental strain generated on the model after the $21 \mathrm{~mm}$ rainfall are larger than those on the model after the $7.6 \mathrm{~mm}$ rainfall. It suggests a high intensity precipitation is more likely to cause a brown coal batter failure. 
3. The safety factor was increased to 1.43 with the emergency buttress, which was even higher than the safety factor (1.38) of the original north batter. There is no apparent incremental displacement or incremental strain on the batter model with buttress. In actual the movements of cracks had been under control with the buttress according to the monitored data. This emergency buttress effectively strengthened the stability of north batter.

4. Plaxis 3D can effectively study the slope stability problem in brown coal open pit mining that is coupled with the effect of rainfall and groundwater flow.

\section{ACKNOWLEDGEMENTS}

The authors sincerely express their appreciation to Maddingley Brown Coal Pty Ltd for their support of this research project, in particular, to Mr. Tim Tillig, Environmental, Quality \& Safety Officer.

\section{REFERENCE}

Australian Government Bureau of Meteorology (2013) Climate Data Online. Retrieved from http://www.bom.gov.au/climate/data/index.shtml?bookmark=136

Chang KT, Huang HC (2015) Three-dimensional analysis of a deep-seated landslide in central Taiwan. Environmental Earth Sciences. doi:10.1007/s12665-015-4128-x

Chen JF, Liu JX, Xue JF, Shi ZM (2014) Failure analyses of a reinforced embankment by strength reduction and limit equilibrium methods considering hardening of soft clay. KSCE journal of Civil Engineering. doi:10.1007/s12205-014-0288-6

Djerbal L, Melbouci B (2015) Numerical modeling of the climate effect on the evolution of the landslide of Ain El Hammam (Algeria). Engineering Geology for Society and Territory.

doi:10.1007/978-3-319-09057-3_220

Duncan JM (1996) State of the art: limit equilibrium and finite element analysis of slopes. J Geotech Eng 122(7):577-596

Durie RA (1991) The Science of Victorian Brown Coal: Structure, Properties and Consequences for Utilization. Butterworth Heinemann. 
Hepburn S (2014) Accidents or bad regulation? Why Victoria's coal mines keep failing. THE

AUSTRALIAN. http://www.theaustralian.com.au/business/business-spectator/accidents-or-badregulation-why-victorias-coal-mines-keep-failing/news-story/eaaba87b0ea5119a28c97393fd1dbd73

Jamsawang P, Boathong P, Mairaing W, Jongpradist P (2015) Undrained creep failure of a drainage canal slope stabilized with deep cement mixing columns. Landslides. doi:10.1007/s10346-015-0651-9

Kulatilake PHSW, Shu B (2015) Prediction of rock mass deformation in three dimensions for a part of an open pit mine and comparison with field deformation monitoring data. Geotechnical and Geological Engineering. doi:10.1007/s10706-015-9921-5

Learmonth AP (1985) Geomechanics working in the power industry. The national Engineering Conference, Melbourne.

Liu K, Mackay R, Xue J, Tolooiyan A (2014) Experimental study of brown coal hydraulic behavior at low confining stress. Unsaturated Soils: Research and Applications - Proceedings of the 6th International Conference on Unsaturated Soils, Sydney, pp. 1125-1130

Liu K, Xue J, Yang M (2016) Deformation behaviour of geotechnical materials with gas bubbles and time dependent compressible organic matter. Engineering Geology Volume 213, 4 November 2016, Pages 98-106

Maiorano RMS, Russo G, Viggiani C (2014) A landslide in stiff, intact clay. Acta Geotechnica. doi:10.1007/s11440-013-0249-0

$\begin{array}{lllll}\text { Mining Warden (2008) Yallourn } & \text { Mine } & \text { Batter } & \text { Failure } & \text { Inquiry. } \\ \text { http://eagcg.org/common/pdf/Yallourn.pdf }\end{array}$

Newcomb SR, Pilkington T, Raisbeck D (1988) Stability and earth movements on the western batters of Yallourn Open Cut Mine. Fifth Australia- New Zealand Conference on Geomechanics Sydney

Ozbay A, Cabalar AF (2015) FEM and LEM stability analyses of the fatal landslides at Çöllolar opencast lignite mine in Elbistan, Turkey. Landslides. doi:10.1007/s10346-014-0537-2

Rosengren KJ (1961) The structure and strength of Victoria brown coal. MSc thesis, University of Melbourne 
Scott B, Ranjith G, Choi SK, Khandelwal M (2010) A review on existing opencast coal mining methods within Australia. Journal of Mining Science. doi:10.1007/s10913-010-0036-3

Tolooiyan A, Mackay R, Xue J (2014) Measurement of the tensile strength of organic soft rock. Geotechnical Testing Journal. doi:10.1520/GTJ20140028

Trollope DH, Rosengren KJ, Brown ET (1965) The mechanics of brown coal. Ge'otechnique, 15, $363-386$

Usluogullari OF, Temugan A, Duman ES (2015) Comparison of slope stabilization methods by threedimensional finite element analysis. Natural Hazards. doi:10.1007/s11069-015-2118-7

Washusen JA, Fraser CJ (1982) Stability control and monitoring in deep Latrobe Valley Open Cuts. The Aus.I.M.M. Conference, Melbourne, Vic.

Xue J, Tolooiyan A (2012) Reliability analysis of block sliding in large brown coal open cuts. The 2012 World Congress on Advances in Civil, Environmental, and Materials Research (ACEM' 12), 1578-1587, Seoul, Korea 